\title{
Performance Evaluation of the PowerChek MERS (upE \& ORF1a) Real-Time PCR Kit for the Detection of Middle East Respiratory Syndrome Coronavirus RNA
}

Hee Jae Huh, M.D. ${ }^{1}$, Ji-Youn Kim, M.T. ${ }^{2}$, Hyeon Jeong Kwon, M.T. ${ }^{2}$, Sun Ae Yun, M.T. ${ }^{2}$, Myoung-Keun Lee, M.T. ${ }^{1}$, Chang-Seok Ki, M.D. ${ }^{1}$, Nam Yong Lee, M.D. ${ }^{1}$, and Jong-Won Kim, M.D. ${ }^{1}$

Department of Laboratory Medicine and Genetics ${ }^{1}$, Samsung Medical Center, Sungkyunkwan University School of Medicine, Seoul; Center for Clinical Medicine ${ }^{2}$, Samsung Biomedical Research Institute, Samsung Medical Center, Seoul, Korea

Background: Molecular detection of Middle East respiratory syndrome coronavirus (MERSCoV) using real-time reverse transcription (rRT)-PCR assays is the method of choice for diagnosis of MERS. We evaluated the performance of the PowerChek MERS (upE \& ORF1a) real-time PCR Kit (PowerChek MERS assay; Kogene Biotech, Korea) a one-step rRT-PCR assay for the qualitative detection of MERS-CoV.

Methods: We evaluated PowerChek MERS assay performance in comparison with nested RT-PCR and sequencing of the RNA-dependent RNA polymerase (RdRp) and N genes. To evaluate diagnostic sensitivity and specificity, 100 clinical specimens (50 positive and 50 negative for MERS-CoV) were simultaneously tested by using the PowerChek MERS and sequencing assays. Assay performance, including limit of detection and precision, was evaluated in vitro by using MERS-CoV RNA transcripts. Analytical specificity was evaluated with a diverse collection of 16 respiratory virus-positive clinical specimens and 14 respiratory bacterial isolates.

Results: The 95\% limits of detection of the PowerChek MERS assay for the upE and the open rading frame (ORF) 1a were 16.2 copies/ $\mathrm{LL}$ and 8.2 copies $/ \mu \mathrm{L}$, respectively. No crossreactivity was observed. The diagnostic sensitivity and specificity of the PowerChek MERS assay were both 100\% (95\% confidence interval, 91.1-100\%).

Conclusions: The PowerChek MERS assay is a straightforward and accurate assay for detecting MERS-CoV RNA. The assay will be a useful tool for the rapid diagnosis of MERS and could prove especially important for MERS outbreak control.

Key Words: MERS-CoV, Real-time reverse-transcription PCR, Performance
Received: February 3, 2017

Revision received: March 26, 2017

Accepted: July 12, 2017

Corresponding author: Chang-Seok Ki Department of Laboratory Medicine and Genetics, Samsung Medical Center, Sungkyunkwan University School of Medicine, 81 Irwon-ro, Gangnam-gu, Seoul 06351, Korea

Tel: +82-2-3410-2709

Fax: +82-2-3410-2719

E-mail: changski@skku.edu

(C) Korean Society for Laboratory Medicine This is an Open Access article distributed under the terms of the Creative Commons Attribution Non-Commercial License (http://creativecommons.org/licenses/by-nc/4.0) which permits unrestricted non-commercial use, distribution, and reproduction in any medium, provided the original work is properly cited.

\section{INTRODUCTION}

For effective control of potential outbreaks of Middle East respiratory syndrome (MERS), highly sensitive and specific laboratory diagnostic tests are needed. Nucleic acid amplification assays are the method most widely used to provide laboratory confirmation of MERS [1]. MERS cases are routinely confirmed based on the detection of unique MERS coronavirus (MERSCoV) RNA sequences by real-time reverse-transcription ( $r R T$ )PCR, with confirmation by nucleic acid sequencing when necessary [2]. The WHO recently published updated interim recommendations for MERS-CoV laboratory testing and recommends an rRT-PCR assay targeting the envelope (upE) gene for screening, followed by confirmation with an assay for the re- 
gions encoding either the open reading frame (ORF)1a, ORF1b, or the nucleocapsid protein $(\mathrm{N})$. For sequencing, two target sites on the MERS-CoV genome, the RNA-dependent RNA polymerase (RdRp) and N genes, are suggested [2-4].

Although commercial rRT-PCR assays for MERS-CoV detection have been developed by several manufacturers, including Altona Diagnostics, Fast Track Diagnostics, and Primerdesign Ltd., studies validating diagnostic performance using authentic specimens are lacking $[5,6]$.

We evaluated the analytical performance and clinical applicability of the PowerChek MERS (upE \& ORFla) real-time PCR Kit (PowerChek MERS assay; Kogene Biotech, Seoul, Korea). The PowerChek MERS assay is a recently developed one-step rRTPCR assay for the qualitative detection of MERS-CoV-specific RNA that has received Conformity Europe-In Vitro Diagnostic (CE-IVD) and the Ministry of Food and Drug Safety (MFDS) of Korea approval. Probes specific for the upE, ORFla, and internal control regions are labeled with the carboxy-fluorescein (FAM), 6-carboxy-4', 5'-dichloro-2',7'-dimethoxy-fluorescein (JOE), and indodicarbocyanine (Cy5) fluorophores, respectively. This assay has been previously evaluated with only small number of clinical specimens [6]. This report presents the results of a performance evaluation of the PowerChek MERS assay using clinical respiratory specimens.

\section{METHODS}

\section{Clinical specimens}

The Institutional Review Board of the Samsung Medical Center, Seoul, Korea, approved this study. For analysis, 100 clinical respiratory specimens (90 sputa and 10 nasopharyngeal swabs) were collected from 100 different individuals from June to July 2015. Fifty specimens were obtained from symptomatic MERSpositive patients, and the remaining 50 were obtained from asymptomatic MERS-negative healthcare workers who were under active monitoring.

Total nucleic acid was extracted by using the QIAamp DSP Viral RNA Mini kit (Qiagen, Hilden, Germany), according to the manufacturer's instructions. A total of $140 \mu \mathrm{L}$ of specimen was used, and the RNA was eluted in $50 \mu \mathrm{L}$ and stored at $-70^{\circ} \mathrm{C}$ until testing with the PowerChek MERS and sequencing assays.

\section{PowerChek MERS (upE and ORF1a) real-time PCR, RdRp, and $\mathrm{N}$ gene sequencing assays}

MERS-CoV RNA was detected by using the PowerChek MERS assay for amplification of upE and ORF1a. The primers and probes were used according to the previous study [3]. All rRTPCR reactions were performed by using the 7500 Fast RealTime PCR System (Applied Biosystems, Foster City, CA, USA). The PCR reaction was performed in a total volume of $20 \mu \mathrm{L}$ (15 $\mu \mathrm{L}$ PCR reaction mixture and $5 \mu \mathrm{L}$ template RNA). Thermocycling conditions were as follows: $50^{\circ} \mathrm{C}$ for $30 \mathrm{~min}$, followed by $95^{\circ} \mathrm{C}$ for $10 \mathrm{~min}$, and then 40 cycles of $15 \mathrm{sec}$ at $95^{\circ} \mathrm{C}$ and 60 $\mathrm{sec}$ at $60^{\circ} \mathrm{C}$. Viral template-positive controls and no-template controls were included in each run. The glyceraldehyde-3-phosphate dehydrogenase (GAPDH) gene was amplified simultaneously as a heterologous endogenous internal control to monitor PCR inhibition and specimen quality. A positive test result was defined as a well-defined exponential fluorescence curve that crossed the threshold $\leq 37$ cycles, $\leq 38$ cycles, and $\leq 35$ cycles for the upE, ORFla, and GAPDH genes, respectively.

Nested RT-PCR and sequencing targeting the RdRp and N genes were performed for confirmation, according to the previous protocols [4]. Briefly, the first round of RT-PCR for the two genes was performed by using the primer sets described in the previous report. A second round was conducted if no product was visible by agarose gel electrophoresis after the first round [4]. PCR products were sequenced by using a 3730 DNA analyzer (Applied Biosystems).

\section{Analytical performance of the PowerChek MERS (upE and ORF1a) real-time PCR Kit}

MERS-CoV RNA transcripts were synthesized in vitro from the T7 promoter, as previously reported [7] and were used for analytical performance evaluation. The limit of detection (LOD), the point at which $95 \%$ of the replicates of a given viral load are detected, was determined by using in vitro RNA transcripts diluted in nuclease-free water. Serial dilutions were analyzed, with 20 replicates per dilution. Probit analysis was used to determine the 95\% LOD. Reproducibility, repeatability, and lot-to-lot precision were determined by using three concentrations (50, 150, and 300 copies $/ \mu \mathrm{L}$ ). Reproducibility was calculated by testing duplicates of each concentration in a single run for five days at two different test sites. Repeatability was calculated by testing duplicates of each concentration in a single run for 20 days. Lot-to-lot precision was accessed by testing duplicates of each concentration in a single run for five days using three different lots. Assay specificity was evaluated with nucleic acids obtained from a diverse collection of 16 respiratory virus-positive clinical specimens and 14 other respiratory bacterial isolates (13 reference strains and one clinical isolate; Table 1). 
Table 1. Analytical specificity of the PowerChek MERS (upE and ORF1a) real-time PCR Kit

\begin{tabular}{|c|c|c|}
\hline Microorganism & Source & $\begin{array}{l}\text { PowerChek } \\
\text { MERS assay }\end{array}$ \\
\hline \multicolumn{3}{|l|}{ Viruses } \\
\hline Adenovirus & Clinical specimen* & Negative \\
\hline Bocavirus & Clinical specimen* & Negative \\
\hline Coronavirus 229E & Clinical specimen* & Negative \\
\hline Coronavirus $0 \mathrm{C} 43$ & Clinical specimen* & Negative \\
\hline Coronavirus HKU1 & Clinical specimen* & Negative \\
\hline Coronavirus NL63 & Clinical specimen* & Negative \\
\hline Human enterovirus & Clinical specimen* & Negative \\
\hline Human metapneumovirus & Clinical specimen* & Negative \\
\hline Human rhinovirus & Clinical specimen* & Negative \\
\hline Influenza A & Clinical specimen* & Negative \\
\hline Influenza B & Clinical specimen* & Negative \\
\hline Parainfluenza 1 & Clinical specimen* & Negative \\
\hline Parainfluenza 2 & Clinical specimen* & Negative \\
\hline Parainfluenza 3 & Clinical specimen* & Negative \\
\hline Respiratory syncytial virus A & Clinical specimen* & Negative \\
\hline Respiratory syncytial virus B & Clinical specimen* & Negative \\
\hline \multicolumn{3}{|l|}{ Bacteria } \\
\hline Acinetobacter baumannii & Reference strain (ATCC 19606) & Negative \\
\hline Escherichia coli & Reference strain (ATCC 25922) & Negative \\
\hline Haemophilus influenza & Reference strain (ATCC 9007) & Negative \\
\hline Klebsiella pneumoniae & Reference strain (ATCC 900603) & Negative \\
\hline Legionella pneumophila & Reference strain (ATCC 33156) & Negative \\
\hline Mycoplasma pneumoniae & Clinical specimen $^{\dagger}$ & Negative \\
\hline Mycobacterium tuberculosis & Reference strain (ATCC 27294) & Negative \\
\hline Mycobacterium avium & $\begin{array}{l}\text { Reference strain } \\
\text { (KMRC 00136-41011) }\end{array}$ & Negative \\
\hline Mycobacterium abscessus & Reference strain (ATCC 19977) & Negative \\
\hline Pseudomonas aeruginosa & Reference strain (ATCC 27853) & Negative \\
\hline Staphylococcus aureus & Reference strain (ATCC 25923) & Negative \\
\hline Staphylococcus epidermidis & Reference strain (ATCC 12228) & Negative \\
\hline Streptococcus pneumoniae & Reference strain (ATCC 49619) & Negative \\
\hline Streptococcus pyogenes & Reference strain (ATCC 19615) & Negative \\
\hline
\end{tabular}

*Specimens that yielded positive results in two respiratory virus panel assays: the AdvanSure RV real-time PCR Kit (LG chem, Seoul, Korea) and the Allplex Respiratory Panel 1, 2, and 3 (Seegene, Seoul, Korea); ${ }^{\dagger}$ Specimens confirmed by sequencing analysis.

Abbreviation: KMRC, Korea Mycobacterium Resource Center.

\section{Diagnostic sensitivity and specificity of the PowerChek MERS (upE and ORF1a) real-time PCR Kit}

The diagnostic performance of the PowerChek MERS assay and the RdRp and $\mathrm{N}$ gene sequencing assay was compared by measuring the positive percent agreement (PPA) and negative percent agreement (NPA) values and kappa coefficients. The
Table 2. Analytical sensitivity of the PowerChek MERS (upE and ORF1a) real-time PCR Kit

\begin{tabular}{lcc}
\hline \multirow{2}{*}{ Concentration (copies/ $\mu \mathrm{L})$} & \multicolumn{2}{c}{ N of detections/N of replicates $(\%)$} \\
\cline { 2 - 3 } & \multicolumn{1}{c}{ upE } & ORF1a \\
\hline 100 & $20 / 20(100)$ & $20 / 20(100)$ \\
50 & $20 / 20(100)$ & $20 / 20(100)$ \\
25 & $20 / 20(100)$ & $20 / 20(100)$ \\
12.5 & $17 / 20(85)$ & $20 / 20(100)$ \\
10 & $18 / 20(90)$ & $19 / 20(95)$ \\
\hline
\end{tabular}

RdRp and $\mathrm{N}$ gene sequencing assay was considered the reference standard method, and the diagnostic sensitivity and specificity of the PowerChek MERS assay were calculated.

\section{Statistical analysis}

Statistical analyses were performed by using the VassarStats website (http://vassarstats.net/) and the SPSS software, version 23.0 (SPSS Inc., Chicago, IL, USA). A $P$ value $<0.05$ was considered statistically significant.

\section{RESULTS}

Table 2 shows the analytical sensitivity of the PowerChek MERS assay. The 95\% LOD of the upE and ORFla regions was 16.2

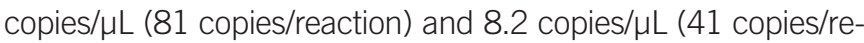
action), respectively. Table 3 shows the precision results for the PowerChek MERS assay. In the reproducibility study, the CV ranged from 0.54 to $2.10 \%$. The assay showed acceptable repeatability, with $\mathrm{CV}$ results ranging from 0.54 to $2.11 \%$. The lotto-lot variation was acceptably low for all concentrations (CV range: $0.49-2.1 \%)$. No false-positive test results were obtained for any of these viral or bacterial isolates, but positive controls were readily detected (Table 1 ).

A comparison of the results of the PowerChek MERS and RdRp and $\mathrm{N}$ gene sequencing assays is shown in Table 4. Both methods gave positive results for all 50 clinical specimens obtained from the symptomatic MERS-positive patients. For all 50 specimens, the PowerChek MERS assay yielded positive reactions for both the upE and ORFla targets. The range of Ct values for the upE, ORF1a, and GAPDH targets was 17.69-32.63, 19.22-34.27, and 18.51-31.17, respectively. Both methods gave negative results for all 50 specimens obtained from asymptomatic MERS-negative individuals. The two assays produced concordant results for all 100 specimens, with a kappa value of 1.00 . The diagnostic sensitivity and specificity of the 
Table 3. Precision of the PowerChek MERS (upE and ORF1a) real-time PCR Kit

\begin{tabular}{|c|c|c|c|c|c|c|c|}
\hline \multirow{3}{*}{ Target } & \multirow{3}{*}{$\begin{array}{l}\text { Concentration } \\
\text { (copies/pL) }\end{array}$} & \multicolumn{6}{|c|}{ Mean Ct (\% coefficient of variation) } \\
\hline & & \multicolumn{2}{|c|}{ Reproducibility } & \multirow{2}{*}{ Repeatability } & \multicolumn{3}{|c|}{ Lot-to-lot variation } \\
\hline & & Site 1 & Site 2 & & Lot 1 & Lot 2 & Lot 3 \\
\hline \multirow[t]{3}{*}{ upE } & 50 & $34.40(2.10)$ & $34.40(1.32)$ & $34.74(2.11)$ & $34.40(2.10)$ & $34.45(3.36)$ & $34.40(2.10)$ \\
\hline & 150 & $32.68(0.89)$ & $32.85(1.19)$ & $32.92(1.06)$ & $32.68(0.89)$ & $32.82(0.97)$ & $32.68(0.89)$ \\
\hline & 300 & $31.91(0.54)$ & $31.99(0.88)$ & $31.97(0.77)$ & $31.91(0.54)$ & $31.98(0.68)$ & $31.91(0.54)$ \\
\hline \multirow[t]{3}{*}{ ORFla } & 50 & $33.93(1.30)$ & $33.90(0.86)$ & $34.07(1.53)$ & $33.93(1.30)$ & $34.14(1.34)$ & $34.04(1.21)$ \\
\hline & 150 & $32.16(0.79)$ & $32.11(0.63)$ & $32.23(0.77)$ & $32.16(0.79)$ & $32.31(0.77)$ & $32.27(0.49)$ \\
\hline & 300 & $30.88(0.62)$ & $30.78(0.62)$ & $30.91(0.54)$ & $30.88(0.62)$ & 30.85 (1.15) & $30.98(0.70)$ \\
\hline
\end{tabular}

Abbreviation: Ct, Cycle threshold.

Table 4. Comparison of the PowerChek MERS (upE and ORFla) real-time PCR Kit and the sequencing assay for the detection of MERS-CoV

\begin{tabular}{llccc}
\hline \multirow{2}{*}{ Detection method } & Result & \multicolumn{2}{c}{ Subject characteristics } & \multirow{2}{*}{ Total } \\
\cline { 3 - 4 } & & $\begin{array}{c}\text { Symptomatic } \\
\text { MERS-confirmed patients }\end{array}$ & $\begin{array}{c}\text { Asymptomatic } \\
\text { MERS-negative individuals }\end{array}$ & \\
\hline PowerChek MERS (upE and ORFla) real-time PCR Kit & Positive & 50 & 0 & 50 \\
& Negative & 0 & 50 & 50 \\
RdRp and N gene sequencing assay & Positive & 50 & 0 & 50 \\
& Negative & 0 & 50 & 50 \\
& Total & 50 & 50 & 100 \\
\hline
\end{tabular}

Positive percent agreement, 100\% (91.1-100\%).

Negative percent agreement, 100\% (91.1-100\%).

Kappa coefficient, 1.00.

Abbreviations: MERS, Middle East respiratory syndrome; RdRp, RNA-dependent RNA polymerase.

PowerChek MERS assay were both 100\% (95\% confidence interval, 91.1-100\%).

\section{DISCUSSION}

To date, various reports have been published on the efficacy of rRT-PCR assays for detection of MERS-CoV-specific RNA that target various regions, including the upE, ORFla, ORF1b, and $N$ genes [3-5, 7-9]. The interim recommendations published by the WHO suggest that the upE assay be used for screening, followed by confirmation with one of the ORF1a, ORF1b, or N gene assays [2]. Similarly, the US Centers for Disease Control and Prevention (CDC) developed and use an rRT-PCR assay composed of two independent PCR reactions; one assay (N2) combined with upE testing for screening, and a second assay (N3) for confirmation of positive results [7, 9]. Previous evaluations of the rRT-PCR assay used mock specimens spiked with cultured MERS-CoV or a small number of clinical specimens from MERS-infected patients [3-5, 7, 8, 10, 11]; this study used a total of 50 authentic clinical specimens from MERS-positive patients with various viral loads.
The PowerChek MERS assay could prevent misjudgment from sampling error, since it uses an endogenous internal control. The use of endogenous internal control would be helpful than that of artificial targets, since the endogenous internal control enables monitoring of not only the RNA extraction and reverse transcription steps but specimen quality as well [12, 13]. Monitoring specimen quality is important because assay performance for detection of MERS-CoV is dependent on specimen quality [14].

The PowerChek MERS assay is both simple and efficient, reducing the workload required for diagnosis. For rRT-PCR, the assay requires mixing of only the premix and RNA, which reduces the hands-on time and the risk of technical errors [5, 15]. The turnaround time from RNA extraction to final result is $3 \mathrm{hr}$. This rapid and simple testing technique would be especially useful in managing a large MERS outbreak.

Our study has several limitations. First, the PowerChek MERS assay was validated with only upper and lower respiratory specimens. Furthermore, the 50 clinical specimens from MERS-confirmed patients were all sputum specimens. Although lower respiratory specimens are the preferred specimen type for initial 
MERS diagnosis because of their higher MERS-CoV load, rRTPCR testing using other specimen types, including serum, urine, and stool specimens, is required in MERS-confirmed cases [2, 16, 17]. Thus, further study to evaluate performance using other specimen types is needed. Second, we did not compare assay performance across different real-time PCR platforms. The PowerChek MERS assay was developed to allow flexibility in the choice of real-time PCR platforms, and can be used with the 7500 Fast Real-Time PCR System, CFX96 realtime PCR detection system (Bio-Rad, Hercules, CA, USA), LightCycler 480 (Roche, Mannheim, Germany), Rotor-gene Q (Qiagen, Hilden, Germany), or Mx3005P thermocycler (Agilent Technologies, CA, USA); however, we evaluated the performance using only the 7500 Fast Real-Time PCR system.

In conclusion, the PowerChek MERS assay has good diagnostic performance for detecting MERS-CoV RNA. This straightforward and accurate assay is a useful tool for the rapid diagnosis of MERS and could be especially important in control of a MERS outbreak.

\section{Authors' Disclosures of Potential Conflicts of Interest}

No potential conflicts of interest relevant to this article were reported.

\section{Acknowledgments}

This research was supported by a grant (grant number: HD15A3232) from the Korea Centers for Disease Control and Prevention.

\section{REFERENCES}

1. Chan JF, Lau SK, To KK, Cheng VC, Woo PC, Yuen KY. Middle East respiratory syndrome coronavirus: another zoonotic betacoronavirus causing SARS-like disease. Clin Microbiol Rev 2015;28:465-522.

2. World Health Organization. Laboratory testing for Middle East respiratory syndrome coronavirus (MERT-CoV). Interim guidance. http://www.who. int/csr/disease/coronavirus_infections/mers-laboratory-testing/en/ (Updated on June 2015).

3. Corman VM, Eckerle I, Bleicker T, Zaki A, Landt O, Eschbach-Bludau M, et al. Detection of a novel human coronavirus by real-time reverse-tran- scription polymerase chain reaction. Euro Surveill 2012;17. pii:20285.

4. Corman VM, Müller MA, Costabel U, Timm J, Binger T, Meyer B, et al. Assays for laboratory confirmation of novel human coronavirus (hCoVEMC) infections. Euro Surveill 2012;17. pii:20334.

5. Corman VM, Ölschläger S, Wendtner CM, Drexler JF, Hess M, Drosten C. Performance and clinical validation of the RealStar MERS-CoV Kit for detection of Middle East respiratory syndrome coronavirus RNA. J Clin Virol 2014;60:168-71.

6. Kim MN, Ko YJ, Seong MW, Kim JS, Shin BM, Sung H. Analytical and clinical validation of six commercial Middle East Respiratory Syndrome coronavirus RNA detection kits based on real-time reverse-transcription PCR. Ann Lab Med 2016;36:450-6.

7. Lu X, Whitaker B, Sakthivel SK, Kamili S, Rose LE, Lowe L, et al. Realtime reverse transcription-PCR assay panel for Middle East respiratory syndrome coronavirus. J Clin Microbiol 2014;52:67-75.

8. Chan JF, Choi GK, Tsang AK, Tee KM, Lam HY, Yip CC, et al. Development and evaluation of novel real-time reverse transcription-PCR assays with locked nucleic acid probes targeting leader sequences of humanpathogenic coronaviruses. J Clin Microbiol 2015;53:2722-6.

9. Centers for Disease Control and Prevention. Novel coronavirus 2012 real-time RT-PCR assay. http://www.fda.gov/downloads/MedicalDevices/ Safety/EmergencySituations/UCM355572.pdf. (Updated on June 10 2014).

10. Shirato K, Yano T, Senba S, Akachi S, Kobayashi T, Nishinaka T, et al Detection of Middle East respiratory syndrome coronavirus using reverse transcription loop-mediated isothermal amplification (RT-LAMP). Virol J 2014;11:139.

11. Seong MW, Lee SJ, Cho SI, Ko K, Kim MN, Sung H, et al. External quality assessment of MERS-CoV molecular diagnostics during the 2015 korean outbreak. Ann Lab Med 2016;36:230-4.

12. Jung YJ, Kwon HJ, Huh HJ, Ki CS, Lee NY, Kim JW. Comparison of the AdvanSure real-time RT-PCR and Seeplex( (®) RV12 ACE assay for the detection of respiratory viruses. J Virol Methods 2015;224:42-6.

13. Bibby DF, McElarney I, Breuer J, Clark DA. Comparative evaluation of the Seegene Seeplex RV15 and real-time PCR for respiratory virus detection. J Med Virol 2011;83:1469-75.

14. Modjarrad K, Moorthy VS, Ben Embarek P, Van Kerkhove M, Kim J, Kieny MP. A roadmap for MERS-CoV research and product development: report from a World Health Organization consultation. Nat Med 2016;22:701-5.

15. Drosten C, Doerr HW, Lim W, Stöhr K, Niedrig M. SARS molecular detection external quality assurance. Emerg Infect Dis 2004;10:2200-3.

16. Centers for Disease Control and Prevention. Interim guidelines for collecting, handling, and testing clinical specimens from patients under investigation (PUIs) for Middle East Respiratory Syndrome Coronavirus (MERS-CoV). V2.1. http://www.cdc.gov/coronavirus/mers/guidelinesclinical-specimens.html (Updated on June 16, 2015).

17. Korea Ministry of Health and Welfare and Center for Disease Control and Prevention. Guidelins for MERS-CoV control. 4-1ed. http://cdc.go.kr/CDC/ info/CdcKrHealth0289.jsp?menulds=HOME001-MNU2374-MNU2375MNU1509-MNU1913\&fid=5742\&q_type=\&q_value=\&cid=73196\& pageNum $=$. 